\title{
Application of Lactobacillus and Streptococcus from Yoghurt for Kabachnik - Field Synthesis of $\alpha$-Aminophosphonates and Evaluation of their Catalytic Activity Using Molecular Docking
}

\author{
Deepali Agarwal*, Ankita Verma, Jyotsna Dhanik and Virendra Kumar Kasana
}

Department of Chemistry, College of Basic Sciences and Humanities, G.B. Pant University of Agriculture and Technology, Pantnagar 263 145, Uttarakhand, India

*Corresponding author

\section{A B S T R A C T}

\begin{tabular}{|c|}
\hline Keywords \\
\hline $\begin{array}{l}\text { Streptococcus thermophilus, } \\
\text { Lactobacillus delbrueckii ssp. } \\
\text { bulgaricus, Yoghurt, } \alpha \text { - } \\
\text { aminophosphonates, } \\
\text { Molecular docking, Moldock } \\
\text { energy (kcal/mol) }\end{array}$ \\
\hline Article Info \\
\hline $\begin{array}{l}\text { Accepted: } \\
18 \text { April } 2018 \\
\text { Available Online: } \\
10 \text { May } 2018\end{array}$ \\
\hline
\end{tabular}

\section{Keywords}

Streptococcus thermophilus, Yoghurt, Molecular docking, Moldock

10 May 2018
A simple, efficient and environmentally process for one pot three component synthesis of $\alpha$-aminophosphonates by the condensation reaction of diversity of substituted benzaldehyde, amine and triethyl phosphite in the presence of microorganisms and yoghurt as a catalyst at room temperature under solvent free condition is described. The reaction was carried out using bacterial strains viz. Streptococcus thermophilus and Lactobacillus delbrueckii ssp. bulgaricus. Both the bacterial strains were equally efficient for the synthesis of $\alpha$-aminophosphonates. Yoghurt containing both of these bacteria was found to be even more active as a catalyst in terms of reaction time. This green method provides $\alpha$ aminophosphonates in good to excellent yields with high purity in very short reaction time. Molecular docking study was also done in order to further understand the increased catalytic activity of yoghurt as a function of microorganisms present in it. Interaction of substrate i.e. substituted benzaldehyde with crystal structure of dehydrogenase from Streptococcus thermophilus (PDB: 3DZB) and Lactobacillus delbrueckii ssp. bulgaricus (PDB: 2YQ4) was done to obtain moldock energy (kcal/mol).

\section{Introduction}

Development of environmentally benign synthetic methodologies for organic synthesis is one of the challenges to chemists. In addition, the process should be economically viable. Application of green chemistry principles in the field of synthesis has open new vistas for organic chemists to develop innovative, non-hazardous and economically viable processes (Anastas and Warner, 1998; Dichiarante et al., 2010; Horvath and Anastas, 2007; Galuszka et al., 2013). Majority of reactions use hazardous solvent or toxic catalyst. So, the reactions under solvent free condition employing natural catalyst are desirable. In literature a number of synthetic methods are reported in which natural catalysts like pineapple juice (Patil et al., 2011), lemon juice (Patil et al., 2012), clay (Habibi and Marvi, 2006; Ramesh and Raghunathan, 2009), phosphates (Zahouily et al., 2006), animal bone (Riadi et al., 2010) etc. has been employed. $\alpha$ - Aminophosphonates are important compounds as they have wide applications as enzyme inhibitors (Allen et al., 
1989), antibiotics (Atherton et al., 1986), herbicides, fungicides, insecticides (Maier and Spoerri, 1991) and plant growth regulators (Emsley and Hall, 1976). Nucleophilic addition of phosphite to imines catalyzed by oxalic acid (Vahdat et al., 2008), $\mathrm{Al}\left(\mathrm{OTf}_{3}\right)$ (Sobhani and Tashrifi, 2009), $\mathrm{FeCl}_{3}$ (Rezaei et al., 2009), heteropoly acids (Heydari et al., 2007), $\mathrm{SbCl}_{3} / \mathrm{Al}_{2} \mathrm{O}_{3}$ (Ambica et al., 2008), sulfamic acid (Mitragotri et al., 2008), $\mathrm{YbCl}_{3}$ (Xu et al., 2006), silica sulfuric acid (Yang et al., 2009), $\mathrm{ZrOCl}_{2} .8 \mathrm{H}_{2} \mathrm{O}$ (Bhanushali et al., 2009), $\mathrm{ZnO}$ (Kassaee et al., 2009), $\mathrm{BiCl}_{3}$ (Zhan and Li, 2005), Amberlite-IR 120 (Bhattacharya and Rana, 2008), $\mathrm{PPh}_{3}$ (Tian et al., 2009), $\mathrm{TiO}_{2}$ (Hosseini-Sarvari, 2008), CAN (Kasthuraiah et al., 2007) have been reported. However, some of the reported processes are associated with drawbacks like use of solvent, addition reagent, long reaction time, costly and moisture sensitive catalyst. In continuation to our program to develop environmentally benign synthetic methods (Agarwal et al., 2014; Agarwal et al., 2018; Agrwal et al., 2014) we, herein, report the use of yoghurt as a catalyst, as a function of microorganisms present in it, for the synthesis of $\alpha$ - aminophosphonates.

Yoghurt is a one of the milk products of major importance in the Indian sub-continent. It is the most important fermented milk product used in India from times immemorial. The scale of production ranges from household level to industrial scale. To the best of our knowledge we are first to report the use of yoghurt as a catalyst for the synthesis of $\alpha$ aminophosphonates. In addition, molecular docking study was done to obtain moldock energy ( $\mathrm{kcal} / \mathrm{mol})$, to achieve an insight into the interaction of substrate i.e. substituted benzaldehyde with crystal structure of dehydrogenase from Streptococcus thermophilus (PDB: 3DZB) and Lactobacillus delbrueckii ssp. bulgaricus (PDB: 2YQ4) as a receptor.

\section{Materials and Methods}

\section{Culture of microorganism}

Bacterial strains of Streptococcus thermophilus and Lactobacillus delbrueckii ssp. bulgaricus were obtained from Department of Microbiology, GB Pant University of Agriculture and Technology, Pantnagar. Strains were used individually as a catalyst for the synthesis of $\alpha$ aminophosphonates.

\section{General procedure for preparation of yoghurt}

In the preparation of yoghurt, cow's milk was boiled in order to destroy viable organism, cooled to the body temperature and seeded with starter culture from an earlier batch. A starter culture contains combination of Streptococcus thermophilus and Lactobacillus delbrueckii ssp. bulgaricus organism.

Milk was then kept in undisturbed condition at ambient temperature for 4-6 hrs. A smooth homogeneous product having an acidity of 0.9 to 1.0 percent acid was formed. This homogenous product was then stirred to get thick porous yoghurt which was then used as catalyst.

General procedure for the synthesis of $\alpha$ aminophosphonates

A mixture of substituted benzaldehyde (5mmol), aniline (5mmol) and yoghurt/ Streptococcus thermophilus/ Lactobacillus delbrueckii ssp. bulgaricus (0.5g) was taken with triethyl phosphite $(6 \mathrm{mmol})$ in $100 \mathrm{ml}$ round bottom flask and was stirred at room temperature (Scheme 1). After completion of the reaction as indicated by TLC, the reaction mixture was extracted with water and dichloromethane to give pure $\alpha$ aminophosphonate. 


\section{Molecular docking}

Molecular docking study was performed using software Molegro Virtual Docker (Version 2.3) (Bachwani and Kumar, 2011; Mahajan et al., 2014; Thomsen and Christensen, 2006). The protein structure of target enzyme in PDB file and ligand (synthesized compound) in Mol file were imported in MVD, and bond orders, hybridization states, and angles were assigned if missing. Electrostatic type surface of protein was created. Potential binding sites of target protein were obtained by detecting maximum of 5 cavities setting parameters as molecular surface (expanded van der Waals), maximum number of cavities $(\mathrm{n}=5)$, minimum cavity volume (10), probe size (1.20), maximum number of ray checks $(n=16)$, minimum number of ray hits $(n=12)$, and grid resolution (0.80). Keeping all the parameters as default, docking wizard was used to obtain multiple poses and all docking calculations. The best one pose with lowest moldock score was selected manually. Using default parameters maximum 5 cavities were detected in the target protein for potential binding with selected best pose. Sphere center of center of protein with sphere radius $30-33 \mathrm{~A}^{\circ}$ were selected for further docking studies. Moldock score or total energy $(\mathrm{kcal} / \mathrm{mol})$ was obtained for protein-ligand interaction (Ramathilagam et al., 2013).

\section{Results and Discussion}

\section{Synthesis of $\alpha$-aminophosphonates}

Yoghurt is a product obtained by lactose fermentation of cow or buffalo milk or mixed milk through the action of single or mixed strains of lactic acid bacteria. The starter used in the manufacture of yoghurt includes Streptococcus thermophilus and Lactobacillus delbrueckii ssp. bulgaricus. The chemical composition of yoghurt has been reported as fat ranging from $5-9 \%$, protein $3.3-3.4 \%$, ash
$0.75-0.79 \%$ and lactic acid $0.5-1.1 \%$. The $\mathrm{pH}$ of commercial yoghurt is usually in the range of 3.5-4.3 (Bamise and Bamise, 2008; Shima et al., 2012). Reaction of substituted benzaldehyde with amines results in the formation of imines intermediates which subsequently reacts with triethylphosphite to produce the corresponding $\alpha$ aminophosphonates. Further, to explore the possibility of catalytic activity of yoghurt as a function of microorgamisms present in it, the individual reaction was carried out using Streptococcus thermophilus/ Lactobacillus delbrueckii ssp. bulgaricus as catalyst. Percent (\%) yield of $\alpha$-aminophosphonates obtained by multicomponent reaction of substituted benzaldehyde, aniline and triethyl phosphite using yoghurt/ Streptococcus thermophilus/ Lactobacillus delbrueckii ssp. bulgaricus are presented in table 1. Moreover, substituted benzaldehyde with either electron-donating or electron-withdrawing substituent reacted efficiently, giving excellent yield.

\section{Characterization data}

IR spectra were recorded on Brucker FT-IR spectrophotometer using $\mathrm{KBr}$ pellets. ${ }^{1} \mathrm{H}$ NMR spectra were recorded on Brucker AVANCE II $400 \mathrm{MHz}$ instrument using $\mathrm{CDCl}_{3}$ with TMS as internal standard. ${ }^{1} \mathrm{H}$ NMR and IR spectra of synthesized compounds are as follows:

Table 1, Entry A1: Diethyl [1-(phenyl)1phenylamino] methylphosphonate

IR (KBr): 3396, 3212, 1685, 1625, 1265, 763 $\mathrm{cm}^{-1}$.

${ }^{1} \mathrm{H}$ NMR $\left(\mathrm{CDCl}_{3}, \mathrm{TMS}\right): \delta(\mathrm{ppm}) 1.2(3 \mathrm{H}, \mathrm{t}$, $\left.\mathrm{OCH}_{2}-\mathrm{CH}_{3}\right), 1.35\left(3 \mathrm{H}, \mathrm{t}, \mathrm{OCH}_{2}-\mathrm{CH}_{3}\right), 3.55$ $\left(1 \mathrm{H}, \mathrm{m}, \mathrm{OCH}_{2}-\mathrm{CH}_{3}\right), 3.7\left(1 \mathrm{H}, \mathrm{m}, \mathrm{OCH}_{2}-\mathrm{CH}_{3}\right)$, $4.15\left(2 \mathrm{H}, \mathrm{m}, \mathrm{OCH}_{2}-\mathrm{CH}_{3}\right), 5.15(1 \mathrm{H}$, br s, N$\mathrm{H})$, 4.6-4.7 (1H, dd, NH-CH), 6.95-7.55 (10H, $\mathrm{m}, \mathrm{Ar}-\mathrm{H})$. 
Table 1, Entry A2: Diethyl [1-(3-nitrophenyl)1phenylamino] methylphosphonate

IR (KBr): 3280, 1592, 1269, 1108, $811 \mathrm{~cm}^{-1}$.

${ }^{1} \mathrm{H}$ NMR (CDCl 3 , TMS): $\delta(\mathrm{ppm}) 1.35(3 \mathrm{H}, \mathrm{t}$, $\left.\mathrm{OCH}_{2}-\mathrm{CH}_{3}\right), 1.6\left(3 \mathrm{H}, \mathrm{t}, \mathrm{OCH}_{2}-\mathrm{CH}_{3}\right), 3.6-3.75$ $\left(1 \mathrm{H}, \mathrm{m}, \mathrm{OCH}_{2}-\mathrm{CH}_{3}\right)$,

4.25-4.35 (1H, m, $\left.\mathrm{OCH}_{2}-\mathrm{CH}_{3}\right), 4.5-4.7(2 \mathrm{H}$, $\left.\mathrm{m}, \mathrm{OCH}_{2}-\mathrm{CH}_{3}\right), 5.25(1 \mathrm{H}$, br s, N-H), $5.4(1 \mathrm{H}$, dd, NH-CH-), 6.9-8.5 (9H, m, Ar-H).

Table 1, Entry A3: Diethyl [1-(4chlorophenyl)-1phenylamino]

methylphosphonate

IR (KBr): 3312, 3368, 1575, 1276, 1078, 767 $\mathrm{cm}^{-1}$.

${ }^{1} \mathrm{H}$ NMR $\left(\mathrm{CDCl}_{3}, \mathrm{TMS}\right): \delta(\mathrm{ppm}) 1.2(3 \mathrm{H}, \mathrm{t}$, $\left.\mathrm{OCH}_{2}-\mathrm{CH}_{3}\right), 1.4\left(3 \mathrm{H}, \mathrm{t}, \mathrm{OCH}_{2}-\mathrm{CH}_{3}\right), 3.3-3.5$ $\left(1 \mathrm{H}, \mathrm{m}, \mathrm{OCH}_{2}-\mathrm{CH}_{3}\right), 3.6-3.7\left(1 \mathrm{H}, \mathrm{m}, \mathrm{OCH}_{2}-\right.$ $\left.\mathrm{CH}_{3}\right), 4.1\left(3 \mathrm{H}, \mathrm{s}, \mathrm{OCH}_{3}\right), 4.3-4.4(2 \mathrm{H}, \mathrm{m}$, $\left.\mathrm{OCH}_{2}-\mathrm{CH}_{3}\right), 4.7(1 \mathrm{H}$, br m, N-H), $5.1(1 \mathrm{H}, \mathrm{dd}$, NH-CH-), 6.8-7.7 (9H, m, Ar-H).
Table 1, Entry A4: Diethyl [1-(4hydroxyphenyl)-1phenylamino] methylphosphonate

IR (KBr): 3312, 3288, 1625, 1263, 1112, 764 $\mathrm{cm}^{-1}$.

${ }^{1} \mathrm{H}$ NMR (CDCl 3 , TMS): $\delta$ (ppm) $1.3(3 \mathrm{H}, \mathrm{t}$, $\left.\mathrm{OCH}_{2}-\mathrm{CH}_{3}\right), 1.45\left(3 \mathrm{H}, \mathrm{t}, \mathrm{OCH}_{2}-\mathrm{CH}_{3}\right), 3.35-$ $3.5\left(1 \mathrm{H}, \mathrm{m}, \mathrm{OCH}_{2}-\mathrm{CH}_{3}\right), 3.85-4.05(1 \mathrm{H}, \mathrm{m}$, $\left.\mathrm{OCH}_{2}-\mathrm{CH}_{3}\right), 4.2\left(3 \mathrm{H}, \mathrm{s}, \mathrm{OCH}_{3}\right), 4.45-4.6(2 \mathrm{H}$, $\left.\mathrm{m}, \mathrm{OCH}_{2}-\mathrm{CH}_{3}\right), 4.85(1 \mathrm{H}$, br m, N-H), 5.1 $(1 \mathrm{H}$, br s, $-\mathrm{OH}), 5.4(1 \mathrm{H}, \mathrm{dd}, \mathrm{NH}-\mathrm{CH}-), 6.95-$ 7.85 (9H, m, Ar-H).

Table 1, Entry A5: Diethyl [1-(4methylphenyl)-1phenylamino]

methylphosphonate

IR (KBr): $3383,1265,1047,784 \mathrm{~cm}^{-1}$.

${ }^{1} \mathrm{H}$ NMR $\left(\mathrm{CDCl}_{3}, \mathrm{TMS}\right): \delta(\mathrm{ppm}) 1.25(3 \mathrm{H}, \mathrm{t}$, $\left.\mathrm{OCH}_{2}-\mathrm{CH}_{3}\right), 1.45\left(3 \mathrm{H}, \mathrm{t}, \mathrm{OCH}_{2}-\mathrm{CH}_{3}\right), 2.35$ $\left(3 \mathrm{H}, \mathrm{s}, \mathrm{CH}_{3}\right), 3.65\left(2 \mathrm{H}, \mathrm{q}, \mathrm{OCH}_{2}-\mathrm{CH}_{3}\right), 4.25$ $\left(2 \mathrm{H}, \mathrm{q}, \mathrm{OCH}_{2}-\mathrm{CH}_{3}\right), 4.4(1 \mathrm{H}$, br m, N-H), 4.65 (1H, dd, NH-CH), 6.8-7.5 (9H, m, Ar-H).

Scheme.1 Synthesis of $\alpha$-aminophosphonates in the presences of yoghurt/ Streptococcus thermophilus/ Lactobacillus delbrueckii ssp. bulgaricus

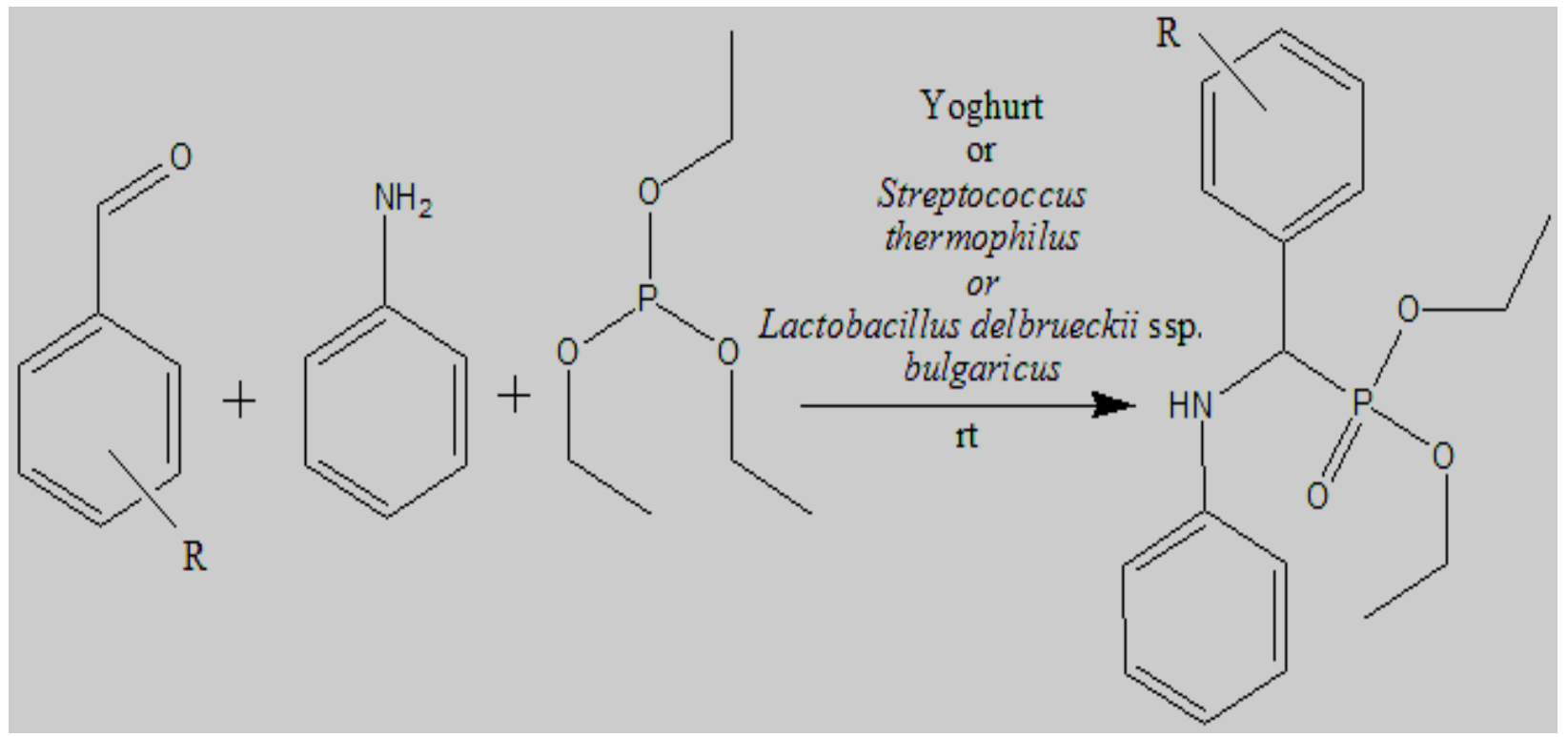


Scheme.2 Plausible mechanism of synthesis of $\alpha$-aminophosphonates

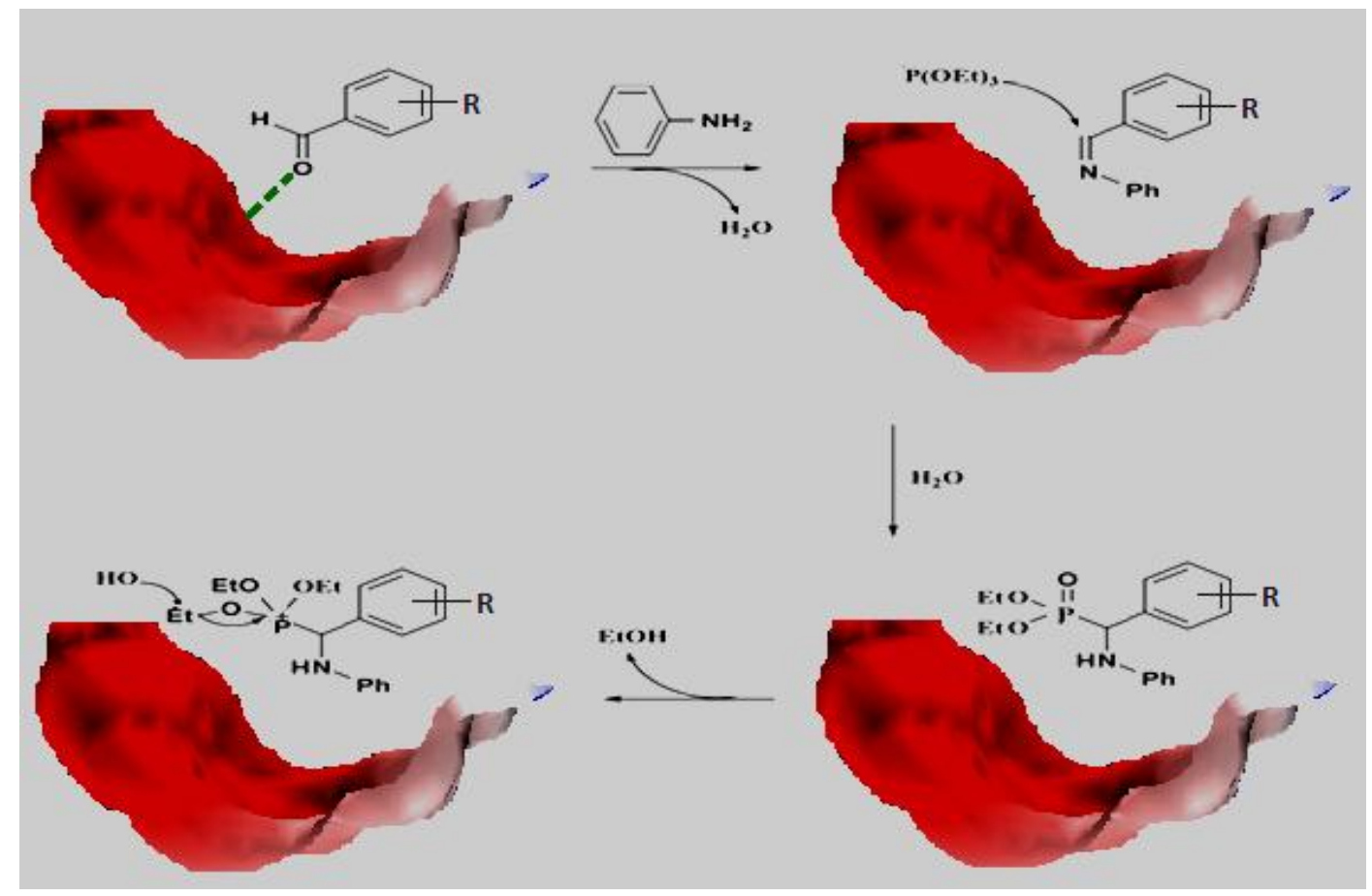

Table.1 Synthesis of $\alpha$-aminophosphonates in the presence of microorganisms

\begin{tabular}{|c|c|c|c|c|c|c|c|c|c|c|}
\hline \multirow[t]{2}{*}{ Entry } & \multirow[t]{2}{*}{$\begin{array}{c}\text { Compound } \\
\text { (R=Substituted } \\
\text { Benzaldehyde) }\end{array}$} & \multicolumn{3}{|c|}{$\begin{array}{l}\text { Yoghurt containing both } \\
\text { Streptococcus thermophilus } \\
\text { (3DZB) and } \\
\text { Lactobacillus delbrueckii } \\
\text { ssp. bulgaricus (2YQ4) }\end{array}$} & \multicolumn{3}{|c|}{$\begin{array}{l}\text { Streptococcus thermophilus } \\
\text { (3DZB) }\end{array}$} & \multicolumn{3}{|c|}{$\begin{array}{l}\text { Lactobacillus delbrueckii } \\
\text { ssp. bulgaricus (2YQ4) }\end{array}$} \\
\hline & & $\begin{array}{c}\% \\
\text { Yield }\end{array}$ & $\begin{array}{l}\text { Time } \\
\text { (min) }\end{array}$ & $\begin{array}{c}\text { MolDock } \\
\text { Energy } \\
\text { (kcal/mol) }\end{array}$ & $\begin{array}{c}\% \\
\text { Yield }\end{array}$ & $\begin{array}{l}\text { Time } \\
(\min )\end{array}$ & $\begin{array}{c}\text { MolDock } \\
\text { Energy } \\
(\text { kcal/mol) }\end{array}$ & $\begin{array}{c}\% \\
\text { Yield }\end{array}$ & $\begin{array}{l}\text { Time } \\
(\text { min) }\end{array}$ & $\begin{array}{c}\text { MolDock } \\
\text { Energy } \\
(\text { kcal } / \mathbf{m o l})\end{array}$ \\
\hline A1. & $\mathrm{R}=\mathrm{H}$ & 89 & 4 & -69.6 & 87 & 35 & -53.8 & 85 & 30 & -58.3 \\
\hline A2. & $\mathrm{R}=3-\mathrm{NO}_{2}$ & 90 & 2 & -84.3 & 86 & 20 & -68.8 & 85 & 15 & -67.7 \\
\hline A3. & $\mathrm{R}=4-\mathrm{Cl}$ & 88 & 3 & -79.1 & 82 & 25 & -59.6 & 87 & 20 & -61.1 \\
\hline A4. & $\mathrm{R}=4-\mathrm{OH}$ & 85 & 3 & -79.1 & 86 & 20 & -62.6 & 84 & 30 & -61.9 \\
\hline A5. & $\mathrm{R}=4-\mathrm{CH}_{3}$ & 88 & 3 & -79.6 & 87 & 30 & -56.8 & 84 & 35 & -61.8 \\
\hline \multicolumn{5}{|c|}{ A1: Diethyl [1-(phenyl)-1phenylamino] methylphosphonate } & \multicolumn{6}{|c|}{$\begin{array}{l}\text { A2: Diethyl [1-(3-nitrophenyl)-1phenylamino] } \\
\text { methylphosphonate }\end{array}$} \\
\hline \multicolumn{5}{|c|}{$\begin{array}{l}\text { A3: Diethyl [1-(4-chlorophenyl)-1phenylamino] } \\
\text { methylphosphonate }\end{array}$} & \multicolumn{6}{|c|}{$\begin{array}{l}\text { A4: Diethyl [1-(4-hydroxyphenyl)-1phenylamino] } \\
\text { methylphosphonate }\end{array}$} \\
\hline \multicolumn{5}{|c|}{$\begin{array}{l}\text { A5: Diethyl [1-(4-methylphenyl)-1phenylamino] } \\
\text { methylphosphonate }\end{array}$} & & & & & & \\
\hline
\end{tabular}


Fig.1 Interaction of substrate i.e. substituted benzaldehyde in the binding site of (1A-5A) 2YQ4, (1B-5B) - 3DZB and (1C-5C) - both, 2YQ4 and 3DZB

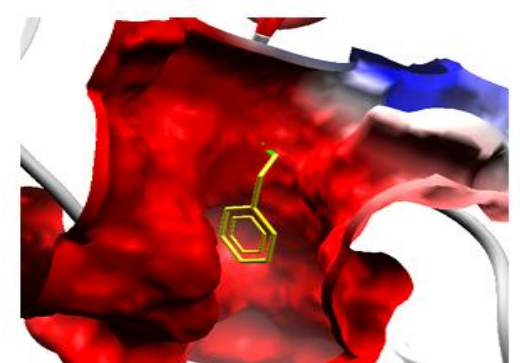

$1 \mathrm{~A}$

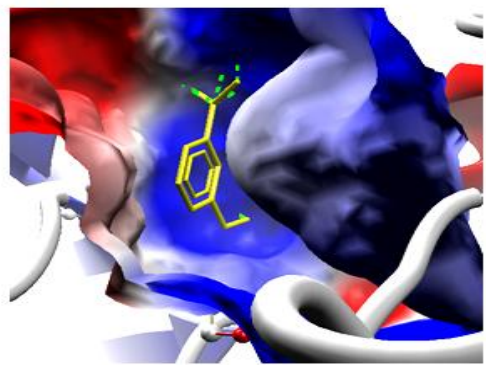

$\mathbf{2 A}$

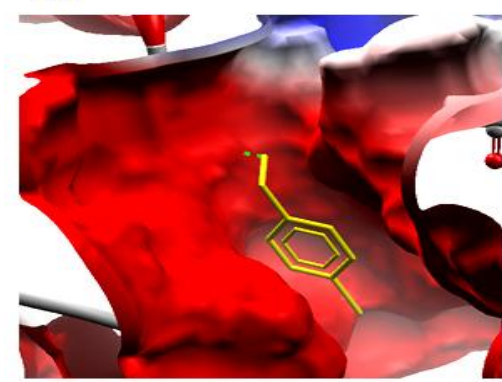

$3 \mathbf{A}$

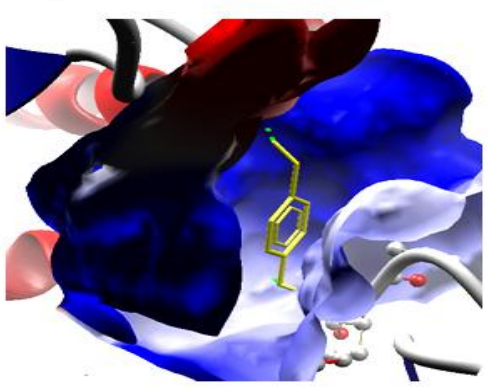

$4 \mathbf{A}$

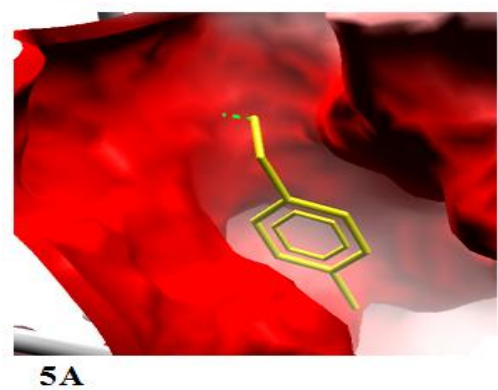

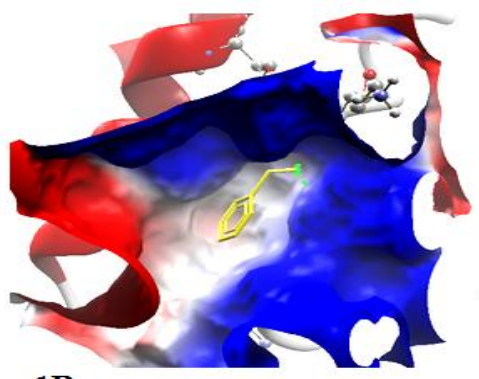

$1 B$

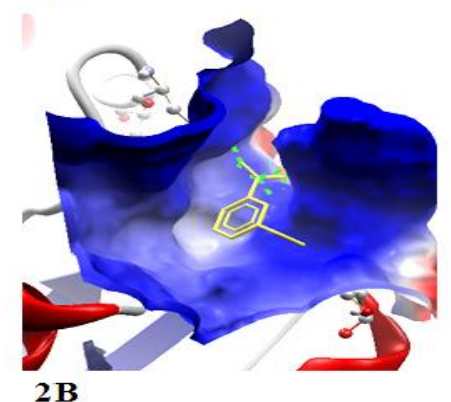

2B
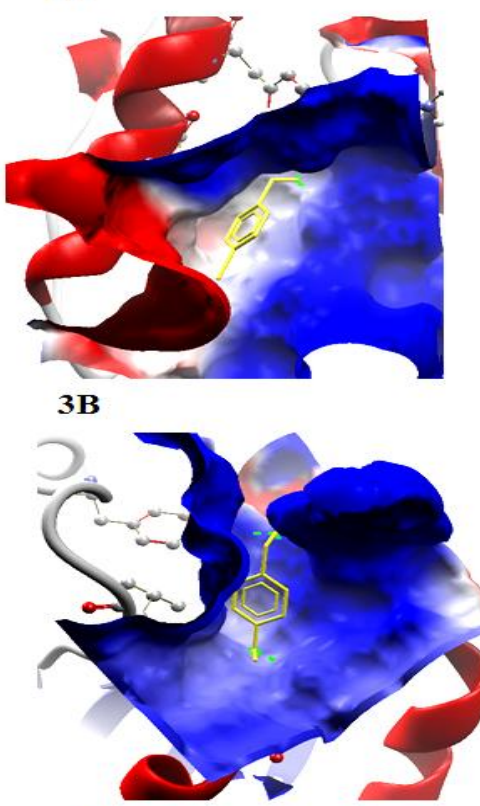

4B

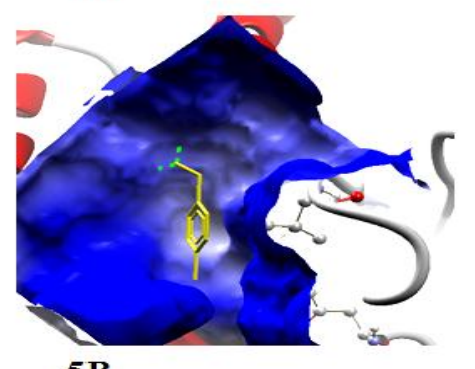

5B

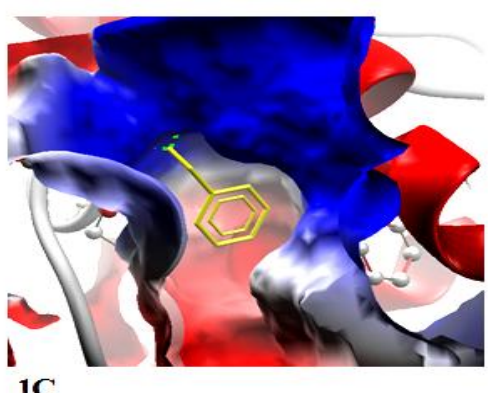

$1 \mathrm{C}$
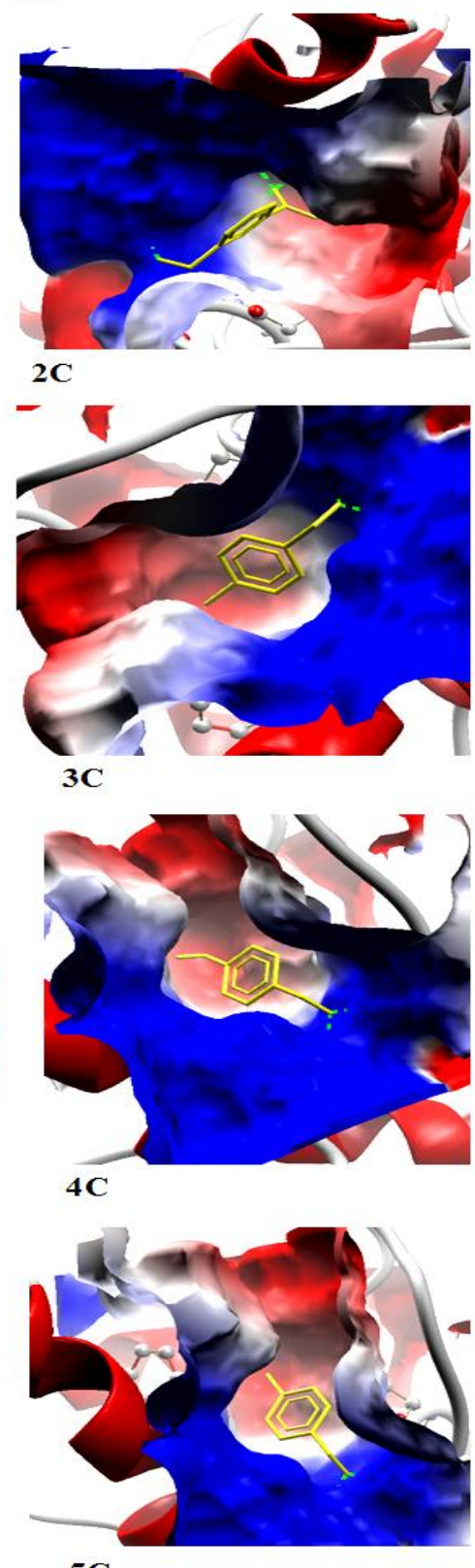

$5 \mathrm{C}$ 


\section{Molecular docking}

Interactions of substituted benzaldehyde with X-ray crystal structure of dehydrogenase from Streptococcus thermophilus (PDB: 3DZB), Lactobacillus delbrueckii ssp. bulgaricus (PDB: 2YQ4) obtained by molecular docking are presented in figure 1 . In figure 1 , images $1 \mathrm{~A}-5 \mathrm{~A}$ represents docking of substituted benzaldehyde with PDB: 2YQ4, images 1B5B with PDB: 3DZB and images $1 \mathrm{C}-5 \mathrm{C}$ with both, PDB: 2YQ4 and PDB: 3DZB. Higher catalytic activity of yoghurt as compared to Streptococcus thermophilus and Lactobacillus delbrueckii ssp. bulgaricus can be explained on the basis of moldock energy $(\mathrm{kcal} / \mathrm{mol})$. Binding of substituted banzaldehyde with both crystal structures PDB: 2YQ4 and PDB: 3DZB gave rise to higher negative moldock energy as compared to Streptococcus thermophilus and Lactobacillus delbrueckii ssp. bulgaricus (Table 1), explaining increased catalytic activity of yoghurt.

The role of microorganisms (Streptococcus thermophilus and Lactobacillus delbrueckii ssp. bulgaricus) present in yoghurt as a catalyst has been proposed to increase the polarity of carbonyl group by binding with carbonyl oxygen which enhances the electrophilicity of the carbonyl carbon consequently increasing the reaction rate (leading high negative moldock energy $(\mathrm{kcal} / \mathrm{mol}) \quad$ (Table 1). The plausible mechanism of this reaction is believed to involve condensation between a carbonyl compound and an amine leading to in situ formation of the activated imine so that addition of phosphite is facilitated to afford phosphonium intermediate, which then undergoes reaction with water generated during the formation of imine to give $\alpha$ aminophosphonates and ethanol (Scheme 2).

Thus, this article describes a simple and efficient method for the green synthesis of $\alpha$ - aminophosphonates derivatives through multicomponent one-pot protocol at room temperature under solvent-free condition using Streptococcus thermophilus, Lactobacillus delbrueckii ssp. bulgaricus and yoghurt as a function of microorganisms present in it. This method is found to be more advantageous as yoghurt offers the convenient, environmentally benign and inexpensive green approach for one pot synthesis of $\alpha$-aminophosphonates within very short reaction time. Molecular docking on the basis of higher negative moldock energy $(\mathrm{kcal} / \mathrm{mol})$ described higher catalytic activity of yoghurt in comparison to Streptococcus thermophilus, Lactobacillus delbrueckii ssp. bulgaricus in terms of reaction time.

\section{Acknowledgement}

Authors are sincerely thankful to DST, New Delhi for the award of DST-INSPIRE Fellowship. Authors also gratefully acknowledge Indian Institute of Chemical Technology, Hyderabad, India for spectral analysis.

\section{References}

Agarwal, D., Agrwal, A., Bairagi, A. and Kasana, V.K. (2014). Hydroxylamine Hydrochloride as an effective Catalyst for Formamide derivative Synthesis and their DPPH scavenging activity. Research Journal of Chemical Sciences. 4(10): 54-57.

Agarwal, D., Verma, A., Dhanik, J. and Kasana, V.K. (2018). Chemometric approach to evaluate catalytic activity of [CTAB/ 18-Crown-6]: A binary catalytic system for one pot green synthesis of 4-benzylidene-3methylisoxazol-5(4H)-one derivatives at room temperature. International Journal of Chemical Studies. 6(2): 3003-3007. 
Agrwal, A., Agarwal, D., Bairagi, A. and Kasana, V.K. (2014). A Mild and Environmentally benign Synthesis of Benzimidazoles: Relevance to the pectin hetero Polysaccharide as a Catalyst. Research Journal of Recent Sciences. 3: 64-67.

Allen, M.C., Fuhrer, W., Tuck, B., Wade, R. and Wood, J.M. (1989). Renin inhibitors. Synthesis of transition-state analog inhibitors containing phosphorus acid derivatives at the scissile bond. Journal of Medicinal Chemistry. 32: 1652-1661.

Ambica, Kumar, S., Taneja, S.C., Hundal, M.S. and Kapoor, K.K. (2008). One-pot synthesis of $\alpha$-aminophosphonates catalysed by antimony trichloride adsorbed on alumina. Tetrahedron Letters. 49: 2208-2212.

Anastas, P.T. and Warner, J.C. (1998). Green Chemistry Theory and Practice. Oxford University Press, New York.

Atherton, F.R., Hassal, C.H. and Lambert, R.W. (1986). Synthesis and structureactivity relationships of antibacterial phosphonopeptides incorporating (1aminoethyl) phosphonic acid and (amino-methyl) phosphonic acid. Journal of Medicinal Chemistry. 29: 2940 .

Bachwani. M. and Kumar, R. (2011). Molecular Docking: A Review. International Journal of Recent Advances in Ayurveda Pharmacy. 2(6): 1746-1751.

Bamise, C.T. and Bamise, O.F. (2008). Quantifying the acidic content of commercial yoghurt drinks in Nigeria. The Internet Journal of Dental Science. 6(1): 8401p.

Bhanushali, M.J., Nandurkar, N.S., Jagtap, S.R. and Bhanage, B.M. (2009). $\mathrm{ZrOCl}_{2} 8 \mathrm{H}_{2} \mathrm{O}$ : An efficient catalyst for one-pot synthesis of $\alpha$ aminophosphonates under solvent-free conditions. Synthetic Communications. 39: 845-859.

Bhattacharya, A.K. and Rana, K.C. (2008). Amberlite-IR 120 catalyzedthreecomponent synthesis of $\alpha$-amino phosphonates in one-pot. Tetrahedron Letters. 49: 2598-2601.

Dichiarante, V., Ravelli, D. and Albini, A. (2010). Green chemistry: state of the art through an analysis of the literature. Green Chemistry Letters and Reviews. 3(2): 105-113.

Emsley, J. and Hall, D. (1976). The Chemistry of Phosphorous. Harper and Row, London.

Galuszka, A., Migaszewski, Z. and Namies, J. (2013). The 12 principles of green analytical chemistry and the significance mnemonic of green analytical practices. Trends in Analytical chemistry. 50: 78-84.

Habibi, D. and Marvi, O. (2006). Montmorillonite KSF and Montmorillonite K-10 Clays as Efficient Catalyst for the Solventless Synthesis a Bismaleimides and Bisphthlimides Using Microwave Irradiation. Arkivoc. 13: 8-15.

Heydari, A., Hamadi, H. and Pourayoubi, M. (2007). A new one-potsynthesis of $\alpha$ amino phosphonates catalyzed by $\mathrm{H}_{3}$ $\mathrm{PW}_{12} \mathrm{O}_{40}$. Catalysis Communications. 8: 1224-1226.

Horvath, I.T. and Anastas, P.T. (2007). Innovations and green chemistry. Chemical Reviews. 107: 2169-2173.

Hosseini-Sarvari, M. (2008). $\mathrm{TiO}_{2}$ as a new and reusable catalyst for one-pot threecomponent syntheses of $\alpha$ aminophosphonates insolvent-free conditions. Tetrahedron. 64: 5459-5466.

Kassaee, M.Z., Movahedi, F. and Masrouri, H. (2009). ZnO nanoparticlesas an efficient catalyst for the one-pot synthesis of $\alpha$-aminophos-phonates. Synlett. 1326. 
Kasthuraiah, M., Kumar, K.A., Reddy, C.S. and Reddy, C.D. (2007). Syntheses, spectral property, and antimicrobial activities of 6 - $\alpha$-amino dibenzo $[\mathrm{d}, \mathrm{f}][1,3,2]$ dioxaphosphepin 6-oxides. Heteroatom Chemistry. 18: 2-8.

Mahajan, A., Gill, N.S. and Arora, R. (2014). A Review on Molecular Docking. International Journal of Recent Advances in Pharmaceutical Research. 4(2): 64-70.

Maier, L. and Spoerri, H. (1991). Organic phosphorus compounds. Resolution of 1-amino-2-(4-fluorophenyl) ethylphosphonic acid as well as some di- and tripeptides. Phosphorus, Sulfur and Silicon and the Related Elements. 61: 69-75.

Mitragotri, S.D., Pore, D.M., Desai, U.V. and Wadgaonkar, P.P. (2008). Sulfamic acid: An efficient and cost-effective solid acid catalyst for the synthesis of $\alpha$ aminophosphonates at ambient temperature. Catalysis Communications. 9: 1822-1826.

Patil, S., Jadhav, D.S. and Mane, S.Y. (2011). Pineapple Juice as a Natural Catalyst: An Excellent Catalyst for Biginelli Reaction. International Journal of Organic Chemistry. 1: 125-131.

Patil, S., Jadhav, S.D. and Patil, U.P. (2012). Natural Acid Catalyzed Synthesis of Schiff Base under Solvent-free Condition: As a Green Approach. Archives of Applied Science Research. 4(2):1074-1078.

Ramathilagam, C., Upgade, A., Bhaskar, A., Umarani, P.R. and Manivannan, V. (2013). Synthesis and molecular docking studies of ethyl 1benzenesulfonyl -2-[(E)-2-(2 methylphenyl) ethenyl] indole -3carboxylate with human renin complexed with inhibitor. Asian Journal of pharmaceutical and Clinical Research. 6(4): 96-99.
Ramesh, E. and Raghunathan, R. (2009). Microwave-Assisted $\mathrm{K}-10$ Montmorillonite Clay-Mediated Knoevenagel Hetero-Diels-Alder Reactions: A Novel Protocol for the Synthesis of Polycyclic Pyrano[2,3,4-kl ]xanthene Deriva-tives. Synthetic Communications. 39(4): 613-625.

Rezaei, Z., Firouzabadi, H., Iranpoor, N., Ghaderi, A., Jafari, M.R., Jafari, A.A. and Zare, H.R. (2009). Design and onepot synthesis of $\alpha$-aminophosphonates and bis ( $\alpha$-aminophosphonates) by iron (III)chloride and cytotoxic activity. European Journal of Medicinal Chemistry. 44: 4266-4275.

Riadi, Y., Mamouni, R., Azzalou, R., Boulahjar, R., Abrouki, Y., Haddad, M.E., Routier, S., Guillaumet, G. and Lazar, S. (2010). Animal bone meal as an efficient catalyst for crossed-aldol condensation. Tetrahedron Letters. 51: 6715-6717.

Shima, A.R.R, Salina, H.F., Masniza, M., Atiqah, A.H. (2012). Viability of lactic acid bacteria in home made yogurt containing sago starch oligosaccharides. International Journal of Basic \& Applied Sciences. 12(01): 58-62.

Sobhani, S. and Tashrifi, Z. (2009). One-pot synthesis of primary 1aminophosphonates: coupling reaction of carbonyl compounds, hexamethyldisilazane and diethyl phosphite catalyzed by $\mathrm{Al}(\mathrm{OTf})_{3}$. Heteroatom Chemistry. 20: 109-115.

Thomsen, R. and Christensen, M.H. (2006). Moldock: A New Technique for HighAccuracy Molecular Docking. Journal of Medicinal Chemistry. 49: 3315-3321.

Tian, Y.P., Wang, F., Xu, Y., Tang, J.J. and Li, H.L. (2009). PPh 3-catalysed onepot three-component syntheses of $\alpha$ aminophosphonates under solvent-free conditions. Journal of Chemical Research. 78-80. 
Vahdat, S.M., Baharfar, R., Tajbakhsh, M., Heydari, A., Baghbanian, S.M. and Khaksar, S. (2008). Organocatalytic synthesis of $\alpha$-hydroxyl and $\alpha$ aminophosphonates. Tetrahedron Letters. 49(46): 6501-6504.

$\mathrm{Xu}, \mathrm{F}$., Luo, Y., Wu, J., Shen, Q. and Chen, H. (2006). Facile one-potsynthesis of $\alpha$ amino phosphonates using lanthanide chloride ascatalyst. Heteroatom Chemistry. 17: 389-392.

Yang, J.J., Dang, J.N. and Chang, Y.W. (2009). Silica sulfuric acid as arecyclable catalyst for a one-pot synthesis of $\alpha$-aminophosphonatesin solvent-free conditions. Letters in Organic Chemistry. 6: 470-473.

Zahouily, M., Mounir, B., Charki, H. Mezdar, A., Bah-Laouan, B. and Ouammou, M. (2006). Investigation of the Basic Catalytic Activity of Natural Phosphates in the Michael Condensation. Arkivoc. 13: $178-186$.

Zhan, Z.P. and Li, J.P. (2005). Bismuth (III) chloride catalyzed three-component coupling synthesis of $\alpha$ aminophosphonates. Synthetic Communications. 35: 2501-2508.

\section{How to cite this article:}

Deepali Agarwal, Ankita Verma, Jyotsna Dhanik and Virendra Kumar Kasana. 2018. Application of Lactobacillus and Streptococcus from Yoghurt for Kabachnik - Field Synthesis of $\alpha$-Aminophosphonates and Evaluation of their Catalytic Activity Using Molecular Docking. Int.J.Curr.Microbiol.App.Sci. 7(05): 2411-2420. doi: https://doi.org/10.20546/ijcmas.2018.705.277 